\title{
Diversity of snake in Kaski district of Gandaki Province, Nepal
}

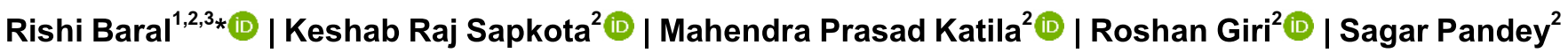 \\ | Aakash Bhandari² ${ }^{2}$ | Abhisek Sapkota ${ }^{2}$ | Ramji Gautam ${ }^{2,3}$ (I)
}

\author{
${ }^{1}$ National Trust for Nature Conservation - Annapurna Conservation Area Project, Hariyo Kharka, Pokhara, Nepal \\ ${ }^{2}$ Snake Conservation Society Nepal, Simpani-1, Pokhara, Nepal \\ ${ }^{3}$ Department of Zoology, Prithvi Narayan Campus, Bhimkalipatan-1, Pokhara, Nepal \\ *Correspondence: right.rishi1@gmail.com
}

Received: 26 October 2020 | Revised: 01 December 2020 | Accepted: 01 December 2020

\begin{abstract}
Snakes are one of the most diverse vertebrates on the globe, mostly prefer arid zones. Nepal harbors a high unrecognized reptilian diversity. Information on the diversity and distribution of snakes in the western Nepal are derived from relatively from old literatures. This study updated the diversity and distribution of snakes from the Kaski district based on rescuing activities, field survey and literature review. Altogether 40 species of snake from five families were recorded in the Kaski district. The family Colubridae (70\%) had the highest species diversity followed by Elapidae (12.5\%), Viperidae (12.5\%), Pythonidae (2.5\%), and Typhlopidae (2.5\%) respectively. Based on the IUCN global status of snake, $5 \%$ are vulnerable, $5 \%$ data deficient, $27.5 \%$ are Least Concern and $62.5 \%$ are Not Evaluated. Six species were found new distribution records in Kaski. Four species were the species listed on CITES II. Out of 40 species, $27.5 \%$ venomous ( $2.5 \%$ were venomous but not fatal to human, $12.5 \%$ were neurotoxic, $12.5 \%$ were hemotoxic which are deadly venomous), $20 \%$ were weakly venomous and not fatal to human and $50 \%$ were non-venomous. Habitat loss, nest destroyed, road-killed and meaningless killing by the negative perception of people was the most threat to snake in Kaski district.
\end{abstract}

Keywords: Hemotoxic, Kaski district, Neurotoxic, Weakly venomous

\section{1 | Introduction}

Reptiles are one of the most widespread diverse vertebrates on the earth and about 11,301 species and 2237 subspecies are currently known. Among them, more than 3500 species of snakes are recorded and out of these only 754 species of them are reported as venomous (Uetz et al. 2020, Scott 2013). Nepal supports high snake diversity (Shah \& Tiwari 2004, Kästle et al. 2013) but most of these records are primarily based on either from presence-only surveys or from anecdotal information.

Snakes found in grassland, cultivate land and forest area. Major determinant affecting the snake distribution is due to the topography and climate. In Nepal, the Arun valley, the Annapurna-Dhaulagiri region and the Chitwan National Park have been extensively studied from the herpetofauna perspective and other few protected areas such as Koshi Tappu, Bardia National Park, Suklaphanta National Park and eastern and central Nepal have also been studied to some extent. But the mid- and far- western regions of Nepal remains least studied due to remoteness and inaccessibility (Shah \& Tiwari 2004).

Snakes are very important to nature and humans which have an ecological niche in the overall pattern of life, providing food for some animals and control over others (Shah \& Tiwari 2004). Snakes are important ecologically, religiously and help to balance the nature (Shrestha \& Shah 1985). The meaningless killing of snake is the main reason of declining their number and species diversity (Shah \& Gautam 2010).

Human and snake conflict is seen more in different place of Nepal which led the snakebites case where Terai region have quite high cases compare to mountain regions (Sharma et al. 2004). A community-based study in South-eastern Nepal showed an annual incidence of 1162 bites/100000, annual mortality rate of $162 / 100000$ and case fatality rate of $27 \%$ (Sharma et al. 2004). This conflict results in negative impact on people that they think all the snakes are venomous and being killed ruthlessly (Shah \& Gautam 2010). 
Nepalese snakes are divided into 5 families of which 3 Typholopidae and Pythonidae are non-venomous, Colubridae have one species venomous i.e Rhabdophis subminiatus and fatal bite cases have been recorded (Shah \& Tiwari 2004) and few are weakly venomous and more species are non-venomous of this family while Elapidae and Viperidae are deadly venomous. Colubridae is the largest family of snakes which contains 2000 species found in the world (Shah \& Tiwari 2004) and 46 species and 6 subspecies of non-venomous and mildly venomous snakes in Nepal. (Shah \& Tiwari 2004). The venomous family of Elapidae contains Cobras, Kraits, and Coral Snakes and represented by 4 genera, 8 species, and 1 subspecies of deadly venomous snakes in Nepal. Cobras have characteristic hood behind the neck (Shah \& Tiwari 2004). This family also includes the king cobra (Ophiophagus hannah) which is the longest venomous snake in the world. In Nepal, Cobras have a religious value where people worship as Kali Nag and Set Nag. Another venomous family of Viperidae contains the vipers and pit viper's snakes which represented by 5 genera, 9 species, and 2 subspecies in Nepal (Shah \& Tiwari 2004).

In the context of Kaski, it provides good habitat for snakes both venomous and non-venomous due to its different topographic feature and climate (Shah \& Gautam 2010). In Pokhara, the previous record of snake's species consists 20 species of snake (Shah \& Gautam 2010). Very few information of snakes is available in Nepal from all protected areas as well as outside protected area. This gives the information of snake's species richness of Kaski district with the aim of raising public awareness to snake conservation.

\section{2 | Materials and methods}

\section{1 | Study area}

Kaski District is a part of Gandaki Pradesh, is one of the seventyseven districts of Nepal. It lies at the latitude of $28^{\circ} 18^{\prime} 19.08^{\prime \prime}$ North and longitude $84^{\circ} 04^{\prime} 37.20^{\prime \prime}$ East. The name is disambiguated from Kaskikot, the ancient Kaski Kingdom (DDC 2015). Kaski covers an area of 2,017 square $\mathrm{km}$ and Pokhara is the district headquarter and had a total population of 492,098 according to 2011 Census. This district lies at the centroid point of the country. The altitude of Kaski district ranges from 450 meters the lowest land to 8091 meters the highest point in the Himalaya range. Kaski District politically has One Metropolitan City, 4 rural municipalities and 3 electoral sectors (DDC
2015). The district is full of rivers such as Seti Gandaki, Modi and Madi along with other rivulets. The district headquarters Pokhara lies about $750 \mathrm{~m}$ above the sea level and is one of the best tourist destinations in the world (DDC 2015).

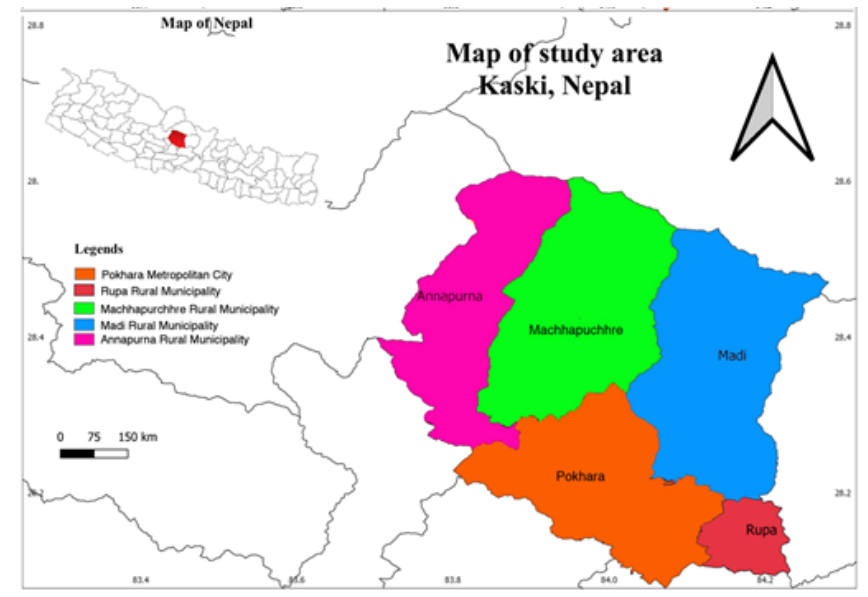

Figure 1. Map of Kaski District

\section{2 | Opportunistic search, rescue events and literature review}

The information of the snakes was collected from different parts of Kaski district from January 2018 to October 2020. The secondary information collected from the previous literature reviewed of Kaski district and list were made. Opportunistic survey (OP) and searches were done through different sources via social media. The rescue data of the team from Snake Conservation Society was collected from three years. Permission and coordination of rescuing was taken from Division Forest Office, Kaski for rescuing the snakes. The number of rescuers was circulated from different social media via Facebook, YouTube so that people called the team for immediate rescue. We identified the snake species by using published guide book Shah and Tiwari (2004), and Kästle and Schleich (2002) the dead specimens were deposited in Annapurna Natural History Museum which was 6 in number.

\section{3 | Results}

A total 40 species (including one subspecies) of snake from five families were recorded from Kaski district (Annex 1). The rescue data of three years 2018- 2020 (up to October) were included. The secondary information was collected from the previous literature review. The family Colubridae $(70 \%)$ had the highest species diversity followed by Elapidae (12.5\%), Viperidae (12.5\%), Pythonidae (2.5\%), and Typhlopidae (2.5\%) respectively. Out of 40 species, five species were neurotoxic, 
deadly venomous, another five species were Hemotoxic, other eight species were weakly venomous and 21 species were non venomous and one species of Colubridae family is venomous i.e Rhabdophis subminiatus (red-necked keelback). Based on thehe IUCN global status of snake consists of two Vulnerable species i.e Python bivittattus and Ophiophagus hannah. Likewise, Liopeltis rappi and Boiga multifasciata were two species which is in data deficient list, 11 were least concern species and the rest are not evaluated in Kaski. Four species were the species which listed on CITES II i.e Python bivittattus, Ptyas mucosa, Naja kaouthia and Ophiophagus hannah from Kaski district. Six species were the species which have new distributional records from Kaski district. Among them, total 23 species were found rescuing from different place of Kaski. Habitat loss, nest destroyed, road-killed and meaningless killing by the negative perception of people was the most threat to snake in Kaski district.
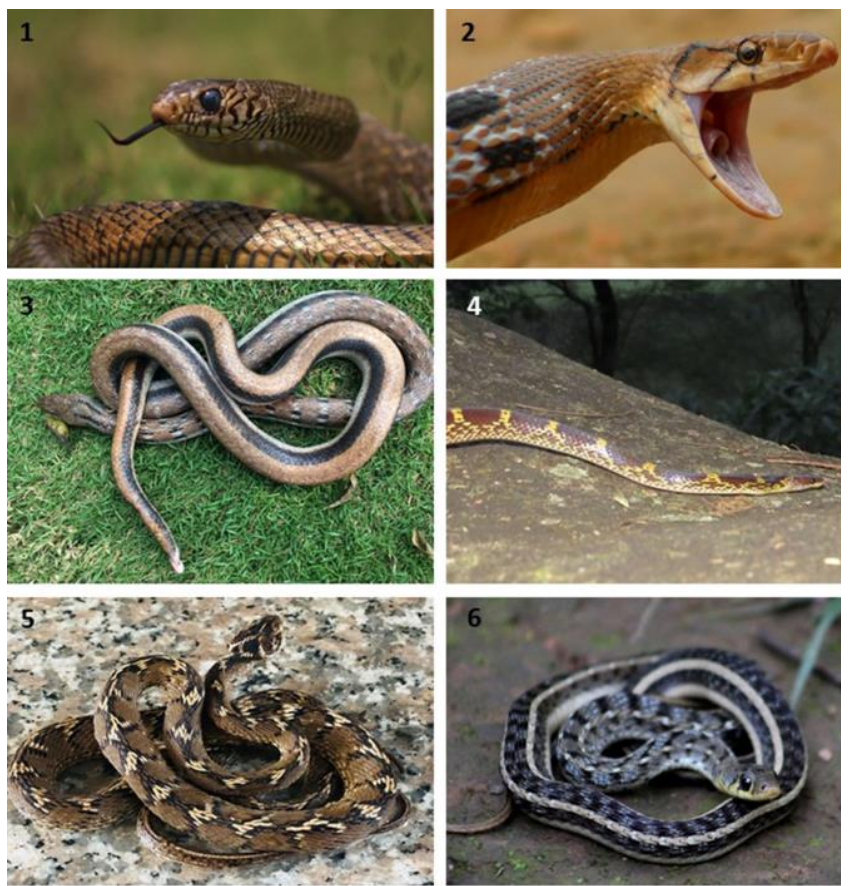

Figure 2. Maximum rescued and seen snake of Colubridae family. Photos: 1Ptyas mucosa (Asiatic rat snake); 2- Coelognathus radiatus (Copper headed trinket snake); 3- Coelognathus helena (Common trinket snake); 4- Lycodon aulicus (Common wolf snake); 5- Boiga trigonata (Common cat snake); and 6Amphiesma stolatum (Buff-striped keelback). (Photos by Rishi Baral)

\section{Colubridae snakes}

The Colubridae family reaches the highest number of species which consists 28 species (including one subspecies) including Ptyas mucosa, Fowlea piscator, Coelognathus helena, Coelognathus radiatus, Amphiesma stolatum, Lycodon aulicus, Boiga trigonata trigonata was found more in Kaski district in compare to other snake species of colubridae family. In Kaski, total eight species were found weakly venomous of this family and one species is venomous i.e Rhabdophis subminiatus (rednecked keelback) and fatal bite case have been recorded (Shah \& Tiwari 2004)

\section{Deadly venomous snakes}
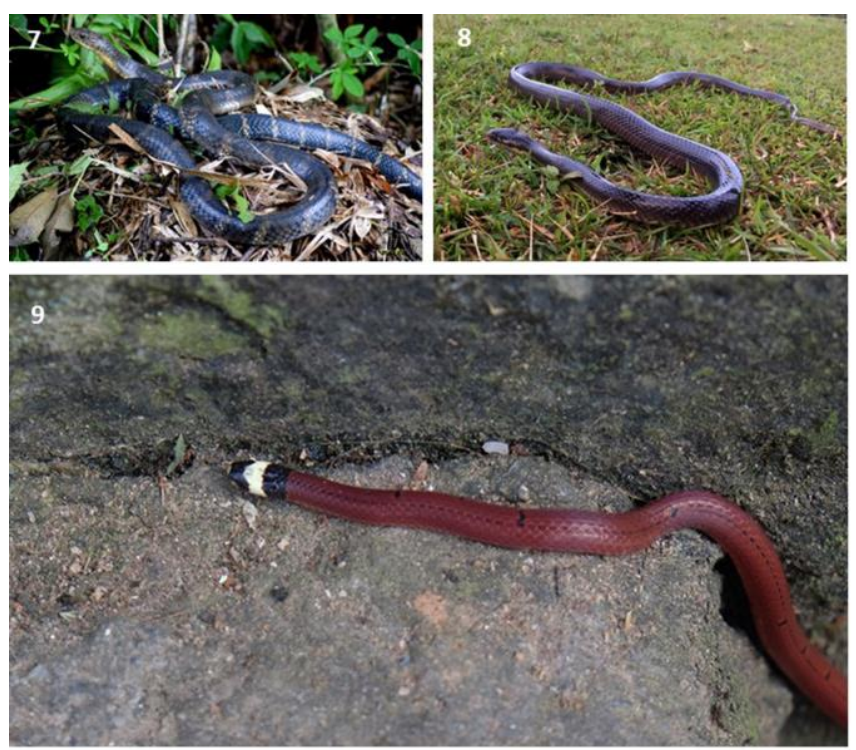

Figure 3. Species of Elapidae family. Photos: 7- Ophiophagus Hannah (King cobra) guarding it's nest in Kaski; 8- Bungarus niger (Greater black krait) (Photos by Rishi Baral). Photo: 9- Sinomicrurus macclellandii univirgatus (Maclelland's coral snake), (Photo by Sangita Gautam)
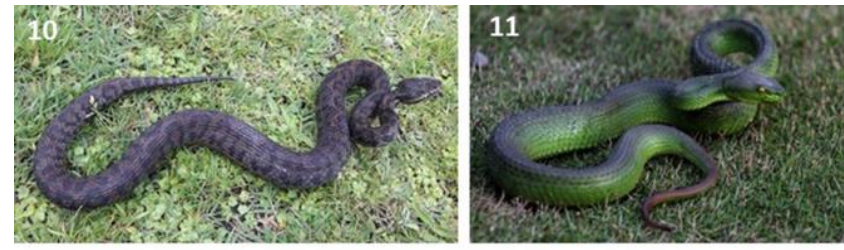

Figure 4. Species of Viperidae family. Photos: 10- Gloydius himalayanus (Himalayan pit viper) (Photo by Mahendra Katila); and 11- Trimeresurus septentrionalis (Kramer's pit viper) (Photo by Rishi Baral)

Out of 40 species, five species were neurotoxic, deadly venomous of family Elapidae and another five species were Hemotoxic, deadly venomous of family Viperidae. In Kaski, total eight species were found weakly venomous and one species was venomous i.e Rhabdophis subminiatus (red-necked keelback) of family Colubridae which cause fatal bite. 20 species were non venomous. The world venomous snake King Cobra was found nesting in Kaski district.

\section{New distribution records of snakes in Kaski district}

The six new distribution records were seen from this area, Rhabdophis subminiatus in 2018, Lycodon jara and Sibynophis sagittarius in 2019, and Lycodon striatus, in 2020 and Naja naja in 2018 and 2019, Naja kaouthia in 2018, 2019 and 2020 (Fig. 5). 


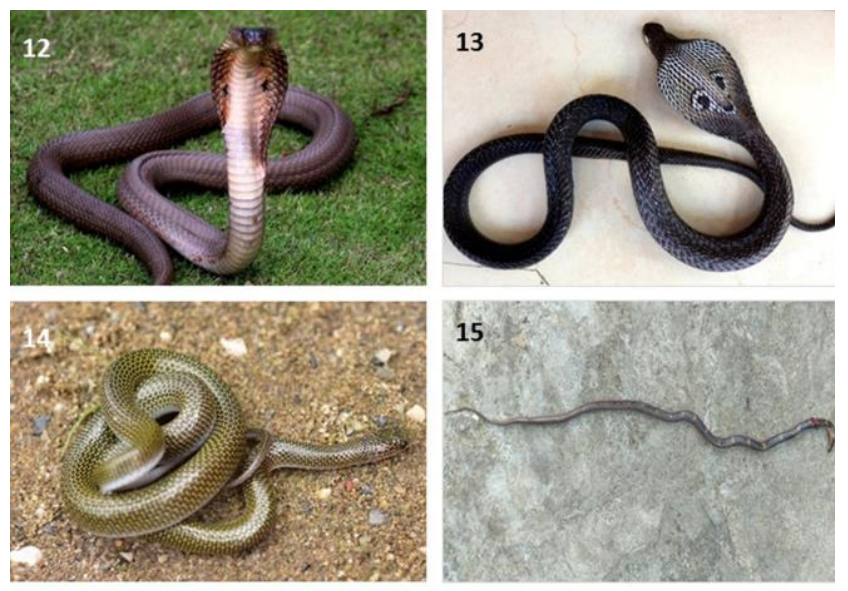

Figure 5. New distribution records of snakes. Photos: 12- Naja kaouthia (Monocled cobra); 13- Naja naja (Spectacled cobra), (Photo by Rishi Baral). Photos: 14- Lycodon jara (Twin-spotted wolf snake) (Photo by Sabin Subedi); 15- Lycodon striatus (Banded wolf snake) dead (Photo by Rajan Gurung)

\section{4 | Discussion}

In Nepal, there are 123 species of reptiles (Schleich \& Kastle 2002. Shah and Tiwari (2004) listed 80 species of serpent in Nepal where Kaski district contain 40 species (including one subspecies) which is $50 \%$ of the country. Nepalese snakes are divided into 5 families of which the families Typholopidae and Pythonidae are non-venomous while Elapidae and Viperidae are venomous (Shah \& Tiwari 2004). But Colubridae have one species venomous i.e. Rhabdophis subminiatus and fatal bite cases have been recorded (Shah \& Tiwari 2004) and few are weakly venomous and more species are non-venomous of this family. All these five families' snakes were present in Kaski district.

The previous research of snakes in Pokhara valley include the 20 species (Shah \& Gautam 2010). And the other researches were from Modi Khola watershed including the Ghandruk region studies by Nanhoe and Ouboter (1987), Shah (2001), Shah and Tiwari (2004), Giri (2013), Project abroad Status report (2018) and (2019) and Kästle et al. (2013) recorded a total of 66 species of amphibians and reptiles from the entire Annapurna Conservation Area. In this study, we recorded 40 species of snakes from the Kaski district. The six new distributional record Rhabdophis subminiatus, Lycodon jara, Sibynophis sagittarius, Lycodon striatus, Naja naja and Naja kaouthia for the first time from Kaski district. The first nest of King Cobra was sighted at Gairi Gau, Dangsing on 2016 at an altitude of 1749 m from Kaski and the $100 \%$ hatching was success (Baral et al. 2019) as well as the first time King cobra was feeding on green pit viper was recorded from Kaski district (Baral \& Koirala 2020) which shows the habitats of Kaski district were favorable for King Cobra. Snake diversity is believed to be exceptionally rich in Nepal due to its great climatic variation and altitude variation from lower terai to high mountain (Shah \& Gautam 2010) and we found $50 \%$ of the snakes were recorded from Kaski which shows the district is favorable and good habitat of many species. But, study of serpent was less in priority although they are equally importance in religious point of view, economically as well as scientifically too. Snakes are very important to nature and humans which have an ecological niche in the overall pattern of life, providing food for some animals. Habitat loss, nest destroyed, road-killed and meaningless killing by the negative perception of people was the most threat to snake in Kaski district (Shah \& Gautam 2010).

\section{5 | Conclusions}

Total $50 \%$ of the country serpent's species were found from the Kaski district with 11 species were venomous where 10 were deadly venomous species including the world's venomous snake too. The Colubridae family reaches the maximum number with one subspecies. We found 15 species in global list, four species in CITES list and six species new distributional record which shows that the Kaski district is highly suitable for different snake's species. Negative perception, road-killed and meaningless killing of people were the main threats to snake species. Conservation and awareness should be necessary to conserve snake species in this area.

\section{Acknowledgements}

We acknowledge National Trust for Nature Conservation, Annapurna Conservation Area Project, Hariyokharka, Pokhara and Unit Conservation Office, Ghandruk, Lwang and Sikles. We thank the community people who call us for rescuing, all the helping hand during the rescue operations. We express our gratitude to Divison forest office, Kaski for making the rescue easy. Many thanks to Prof. Karan Bahadur Shah for his continuous supports to identify the snake species. Special thanks to NTNC-ACAP team including Mr. Raj Kumar Gurung, Narendra Shrestha, Ashok Subedi, Shailendra Kumar Yadav. Likewise, thanks to Siddhartha Bhandari, Prabin Pandey, and whole team of Snake conservation society, Nepal for constant encouragement and valuable advices. We thanks to Rajan Gurung who send the photo to us which is new distribution to Kaski and also thanks to Sangita Gautam and Sabin Subedi. We also thank reviewers for their comments on our manuscript. 


\section{Authors' contributions}

Baral R. collected the data, review all, wrote the manuscript. All authors contributed in rescue event in all three years and approved it for the submission.

\section{Conflicts of interest}

Authors declare no conflict of interest.

\section{ORCID}

Rishi Baral (D) https://orcid.org/0000-0001-6718-0016

Keshab Raj Sapkota iD https://orcid.org/0000-0001-7061-2238

Mahendra Prasad Katila (D) https://orcid.org/0000-0001-5618-832X

Roshan Giri (D) https://orcid.org/0000-0001-7769-8193

Sagar Pandey (D) https://orcid.org/0000-0001-5419-2085

Aakash Bhandari (D) https://orcid.org/0000-0003-2109-9102

Abhisek Sapkota (D) https://orcid.org/0000-0003-2384-9384

Ramjii Gautam (D) https://orcid.org/0000-0003-3344-3556

\section{References}

Baral, R. and Koirala, R. 2020. A King Cobra, Ophiophagus hannah (Cantor 1836), Preying on a Green Pitviper (Trimeresurus sp.) in Nepal. IRCF JOURNAL Reptiles \& Amphibians: Conservation and Natural History 27(2): 211-212.

Baral, R., Yadav, S. K., Gautam, R., Katila, M. P, Gurung, R. K., Subedi, A. and Basnet, B. 2018. Status and distribution of King Cobra in Southern Annapurna Conservation Area, Nepal Friends of Nature, The Himalayan Naturalist 2(1):37-41

Giri, B. 2013. Diversity and Distribution of Amphibians in Annapurna Conservation Area, Nepal. The Rufford Small Grants Foundation, London, UK.

Handbook of District Development Committee, Kaski, 2015. Pokhara, Kaski. 2015. pp 3-5.

Kästle, W., Rai, K. and Schleich. H. H. 2013. Field Guide to Amphibians and Reptiles of Nepal. ARCO-Nepal e.V., München, Germany

Nanhoe, L. M. R. and Ouboter, P. 1987. The distribution of reptiles and amphibians in the Annapurna -Dhaulagiri region (Nepal). Zoölogische Verhandelingen 240:1-105.

Schleich, H. H. and Kastle, W. (Ed). 2002. Amphibians and Reptiles of Nepal. A.R.G. Ganthner Verlag K.G. Germany. pp 1295

Shah, K. B. and Tiwari, S. 2004. Herpetofauna of Nepal: A Conservation Companion IUCN - The world Conservation Union, Nepal. VII +237 pp.
Shah, P. J. and Gautam, R. 2010. Brief survey on the snakes of Pokhara Valley. Journal of Natural History Museum TU, Kathmandu, Nepal 25:252-254.

Tiwari, S. 2004. Herpetofauna of Nepal: A Conservation Companion IUCN - The world Conservation Union, Nepal. VII +237 pp.

Shah, K. B. 2001. Herpetofauna and ethnoherpetology of the southern Annapurna Region, Kaski District, Nepal. Journal of Natural History Museum, Tribhuvan University 20:105-128.

Sharma, S. K., Pandey, D. P., Shah, K. B., Tillack, T., Chappuis, F., Thapa, C. L., et al. 2013. Venomous Snakes of Nepal. A Photographic Guide. B.P. Koirala Institute of Health Sciences, Dharan, Nepal.

Shrestha, R. L and Shaha, K. B. 1985. Nepal ka Sarpaharu (English: Snakes of Nepal). In Nepali, T.U., Natural History Museum 5(1):75-78

Shupe, S. 2013. Venomous snakes of the world. Department of the Navy Bureau of Medicine and Surgery, pp. 320.

Project Abroad Status Report, 2019. A report on the activities and accomplishments of Projects Abroad's Himalayan Mountain Conservation Project in Ghandruk, Nepal for the year 2019.

Project Abroad Status Report, 2018. A report on the activities and accomplishments of Projects Abroad's Himalayan Mountain Conservation Project in Ghandruk, Nepal for the year 2018.

Uetz, P., Freed, P. and Hošek, J. (eds.) 2020. The Reptile Database, http://www.reptile-database.org, Accessed on 20 October 2020

\section{Cite this article as:}

Baral, R., Sapkota, K. R., Katila, M. P., Giri, R., Pandey, M. Bhandari, A., et al. 2020. Diversity of Snake in Kaski district of Gandaki Province, Nepal. Nepalese Journal of Zoology 4(2):101107. https://doi.org/10.3126/njz.v4i2.33892 
Annex 1. List of Snakes found in Kaski districts with their details. Note: OP- Opportunistic record

\begin{tabular}{|c|c|c|c|c|c|c|c|c|c|c|}
\hline S.N. & Species & Common name & $\begin{array}{l}\text { IUCN Global } \\
\text { Status }\end{array}$ & $\begin{array}{l}\text { Venomous/ } \\
\text { Non } \\
\text { Venomous }\end{array}$ & $\begin{array}{l}\text { Source of } \\
\text { Information }\end{array}$ & 2018 & 2019 & 2020 & Rescued & Remarks \\
\hline \multicolumn{11}{|c|}{ Family: Typhlopidae } \\
\hline 1 & $\begin{array}{l}\text { Indotyphlops braminus } \\
\text { (Daudin, 1803) }\end{array}$ & $\begin{array}{l}\text { common blind snake / } \\
\text { Brahminy worm snake/ } \\
\text { flowerpot snake, Brahminy } \\
\text { blindsnake/ bootlace snake }\end{array}$ & Not Evaluated & $\begin{array}{l}\text { Non } \\
\text { Venomous }\end{array}$ & $\begin{array}{l}\mathrm{OP}+ \\
\text { Literature }\end{array}$ & $\checkmark$ & $\checkmark$ & $x$ & & \\
\hline \multicolumn{11}{|c|}{ Family: Pythonidae } \\
\hline 2 & $\begin{array}{l}\text { Python bivittattus (Kuhl, } \\
\text { 1820) }\end{array}$ & Burmese python & $\begin{array}{l}\text { Vulnerable } \\
\text { A2acd }\end{array}$ & $\begin{array}{l}\text { Non } \\
\text { Venomous }\end{array}$ & $\begin{array}{l}\text { OP + } \\
\text { Literature }\end{array}$ & $\checkmark$ & $\checkmark$ & $\checkmark$ & & \\
\hline \multicolumn{11}{|c|}{ Family : Colubridae (Natricidae) } \\
\hline 3 & $\begin{array}{l}\text { Herpetoreas platyceps } \\
\text { (Blyth, 1854) }\end{array}$ & $\begin{array}{l}\text { mountain keelback/ Asiatic } \\
\text { keelback / eastern keelback }\end{array}$ & Not Evaluated. & $\begin{array}{l}\text { Weakly } \\
\text { venomous }\end{array}$ & $\begin{array}{l}\text { OP }+ \\
\text { Literature }\end{array}$ & $\checkmark$ & $\checkmark$ & $\sqrt{ }$ & $\checkmark$ & \\
\hline 4 & $\begin{array}{l}\text { Amphiesma stolatum } \\
\text { (Linnaeus, 1758) }\end{array}$ & buff striped keelback & Not Evaluated. & $\begin{array}{l}\text { Weakly } \\
\text { venomous }\end{array}$ & $\begin{array}{l}\mathrm{OP}+ \\
\text { Literature }\end{array}$ & $\checkmark$ & $\sqrt{ }$ & $\checkmark$ & $\sqrt{ }$ & \\
\hline 5 & $\begin{array}{l}\text { Rhabdophis himalayanus } \\
\text { (Günther, 1864) }\end{array}$ & $\begin{array}{l}\text { Himalayan keelback / } \\
\text { Himalayan boigine snake }\end{array}$ & Not Evaluated. & $\begin{array}{l}\text { Weakly } \\
\text { venomous }\end{array}$ & $\begin{array}{l}\mathrm{OP}+ \\
\text { Literature }\end{array}$ & $\checkmark$ & $x$ & $x$ & $\checkmark$ & \\
\hline 6 & $\begin{array}{l}\text { Rhabdophis subminiatus } \\
\text { (Schlegel, 1837) }\end{array}$ & red-necked keelback & Least Concern & Venomous & Literature & $\checkmark$ & $x$ & $x$ & & $\begin{array}{l}\text { New } \\
\text { distribution } \\
\text { record }\end{array}$ \\
\hline 7 & $\begin{array}{l}\text { Boiga multifasciata (Blyth, } \\
\text { 1861) }\end{array}$ & $\begin{array}{l}\text { many-banded tree snake } \\
\text { /Himalayan cat snake }\end{array}$ & Data Deficient & $\begin{array}{l}\text { Weakly } \\
\text { venomous }\end{array}$ & Literature & $x$ & $x$ & $x$ & & \\
\hline 8 & $\begin{array}{l}\text { Boiga ochracea ochracea } \\
\text { (Theobald, 1868) }\end{array}$ & common tawny cat snake & Not Evaluated. & $\begin{array}{l}\text { Weakly } \\
\text { venomous }\end{array}$ & $\begin{array}{l}\mathrm{OP}+ \\
\text { Literature }\end{array}$ & $\checkmark$ & $x$ & $x$ & & \\
\hline 9 & $\begin{array}{l}\text { Boiga ochracea stoliczkae } \\
\text { (Wall 1909) }\end{array}$ & Stoliczka's tawny cat snake & Not Evaluated. & $\begin{array}{l}\text { Weakly } \\
\text { venomous }\end{array}$ & Literature & $x$ & $x$ & $x$ & & \\
\hline 10 & $\begin{array}{l}\text { Boiga trigonata trigonata } \\
\text { (Schneider, 1802) }\end{array}$ & $\begin{array}{l}\text { common cat snake / } \\
\text { common Indian cat snake / } \\
\text { Indian gamma snake }\end{array}$ & Least Concern & $\begin{array}{l}\text { Weakly } \\
\text { venomous }\end{array}$ & $\begin{array}{l}\text { OP+ } \\
\text { Literature }\end{array}$ & $\checkmark$ & $\checkmark$ & $\checkmark$ & $\checkmark$ & \\
\hline 11 & $\begin{array}{l}\text { Coelognathus helena } \\
\text { (Daudin, 1803) }\end{array}$ & common trinket snake & Not Evaluated. & $\begin{array}{l}\text { Non } \\
\text { Venomous }\end{array}$ & $\begin{array}{l}\mathrm{OP}+ \\
\text { Literature }\end{array}$ & $\checkmark$ & $\sqrt{ }$ & $\sqrt{ }$ & $\sqrt{ }$ & \\
\hline 12 & $\begin{array}{l}\text { Coelognathus radiatus } \\
\text { (Boie, 1827) }\end{array}$ & $\begin{array}{l}\text { Copper headed trinket } \\
\text { snake / Copper headed rat } \\
\text { snake/ Copper headed } \\
\text { racer }\end{array}$ & Not Evaluated. & $\begin{array}{l}\text { Non } \\
\text { Venomous }\end{array}$ & $\begin{array}{l}\mathrm{OP}+ \\
\text { Literature }\end{array}$ & $\sqrt{ }$ & $\checkmark$ & $\checkmark$ & $\sqrt{ }$ & \\
\hline 13 & $\begin{array}{l}\text { Elaphe hodgsoni (Günther, } \\
\text { 1860) }\end{array}$ & $\begin{array}{l}\text { Himalayan trinket snake / } \\
\text { Hodgson's racer }\end{array}$ & Not Evaluated. & $\begin{array}{l}\text { Non } \\
\text { Venomous }\end{array}$ & $\begin{array}{l}\text { OP }+ \\
\text { Literature }\end{array}$ & $\checkmark$ & $x$ & $\sqrt{ }$ & $\sqrt{ }$ & \\
\hline 14 & $\begin{array}{l}\text { Oreocryptophis } \\
\text { porphyraceus (Cantor } \\
1839 \text { ) }\end{array}$ & $\begin{array}{l}\text { black banded trinket } \\
\text { snake/red bamboo snake / } \\
\text { western black-banded } \\
\text { trinket snake }\end{array}$ & Not Evaluated. & $\begin{array}{l}\text { Non } \\
\text { Venomous }\end{array}$ & $\begin{array}{l}\text { OP }+ \\
\text { Literature }\end{array}$ & $\checkmark$ & $x$ & $\sqrt{ }$ & $\sqrt{ }$ & \\
\hline 15 & $\begin{array}{l}\text { Liopeltis rappi (Günther, } \\
\text { 1860) }\end{array}$ & $\begin{array}{l}\text { Himalayan stripe necked } \\
\text { snake }\end{array}$ & Data Deficient & $\begin{array}{l}\text { Non } \\
\text { Venomous }\end{array}$ & $\begin{array}{l}\mathrm{OP}+ \\
\text { Literature }\end{array}$ & $\checkmark$ & $\checkmark$ & $x$ & $\sqrt{ }$ & $\begin{array}{l}\text { Ghandruk } \\
\text { only }\end{array}$ \\
\hline 16 & $\begin{array}{l}\text { Lycodon aulicus (Linnaeus, } \\
1758 \text { ) }\end{array}$ & $\begin{array}{l}\text { common wolf snake /Indian } \\
\text { wolf snake }\end{array}$ & Not Evaluated. & $\begin{array}{l}\text { Non } \\
\text { Venomous }\end{array}$ & $\begin{array}{l}\mathrm{OP}+ \\
\text { Literature }\end{array}$ & $\checkmark$ & $\sqrt{ }$ & $\sqrt{ }$ & $\sqrt{ }$ & \\
\hline 17 & $\begin{array}{l}\text { Lycodon jara (SHAW, } \\
1802 \text { ) }\end{array}$ & twin-spotted wolf snake & Least Concern & $\begin{array}{l}\text { Non } \\
\text { Venomous }\end{array}$ & OP & $x$ & $\checkmark$ & $x$ & $\sqrt{ }$ & $\begin{array}{l}\text { New } \\
\text { distribution } \\
\text { record }\end{array}$ \\
\hline 18 & $\begin{array}{l}\text { Lycodon striatus (SHAW, } \\
1802 \text { ) }\end{array}$ & $\begin{array}{l}\text { banded wolf snake / } \\
\text { northern wolf snake/ barred } \\
\text { wolf snake }\end{array}$ & Not Evaluated. & $\begin{array}{l}\text { Non } \\
\text { Venomous }\end{array}$ & OP & $x$ & $x$ & $\checkmark$ & & $\begin{array}{l}\text { New } \\
\text { distribution } \\
\text { record }\end{array}$ \\
\hline 19 & $\begin{array}{l}\text { Oligodon erythrogaster } \\
\text { (Boulenger, 1907) }\end{array}$ & $\begin{array}{l}\text { Nagarkot kukri snake / Red } \\
\text { bellied kukri snake }\end{array}$ & Not Evaluated. & $\begin{array}{l}\text { Non } \\
\text { Venomous }\end{array}$ & $\begin{array}{l}\text { OP }+ \\
\text { Literature }\end{array}$ & $\checkmark$ & $x$ & $\sqrt{ }$ & $\checkmark$ & \\
\hline 20 & $\begin{array}{l}\text { Oligodon arnensis (Shaw, } \\
\text { 1802) }\end{array}$ & $\begin{array}{l}\text { Russet kukri snake/ } \\
\text { common kukri snake/ } \\
\text { banded kukri }\end{array}$ & Not Evaluated. & $\begin{array}{l}\text { Non } \\
\text { Venomous }\end{array}$ & $\begin{array}{l}\text { OP }+ \\
\text { Literature }\end{array}$ & $x$ & $x$ & $\checkmark$ & $\sqrt{ }$ & \\
\hline 21 & $\begin{array}{l}\text { Pseudoxenodon macrops } \\
\text { (Blyth, 1855) }\end{array}$ & $\begin{array}{l}\text { Indian false cobra / (Large- } \\
\text { eyed or) big-eyed bamboo } \\
\text { snake, Mock cobra }\end{array}$ & Least Concern & $\begin{array}{l}\text { Weakly } \\
\text { venomous }\end{array}$ & $\begin{array}{l}\mathrm{OP}+ \\
\text { Literature }\end{array}$ & $\checkmark$ & $\checkmark$ & $x$ & & \\
\hline
\end{tabular}




\begin{tabular}{|c|c|c|c|c|c|c|c|c|c|c|}
\hline 22 & $\begin{array}{l}\text { Ptyas mucosa ( Linnaeus, } \\
\text { 1758) }\end{array}$ & $\begin{array}{l}\text { Asiatic rat snake / dhaman / } \\
\text { Oriental ratsnake }\end{array}$ & Not Evaluated. & $\begin{array}{l}\text { Non } \\
\text { Venomous }\end{array}$ & $\begin{array}{l}\text { OP }+ \\
\text { Literature }\end{array}$ & $\sqrt{ }$ & $\checkmark$ & $\checkmark$ & $\checkmark$ & \\
\hline 23 & $\begin{array}{l}\text { Sibynophis collaris (Gray, } \\
1853 \text { ) }\end{array}$ & $\begin{array}{l}\text { collared black headed } \\
\text { snake / common black } \\
\text { headed snake / common } \\
\text { many-tooth snake }\end{array}$ & Least Concern & $\begin{array}{l}\text { Non } \\
\text { Venomous }\end{array}$ & $\begin{array}{l}\text { OP+ } \\
\text { Literature }\end{array}$ & $\sqrt{ }$ & $x$ & $\mathrm{x}$ & $\sqrt{ }$ & \\
\hline 24 & $\begin{array}{l}\text { Sibynophis sagittarius } \\
\text { (Cantor, 1839) }\end{array}$ & $\begin{array}{l}\text { Cantor's black headed } \\
\text { snake }\end{array}$ & Not Evaluated. & $\begin{array}{l}\text { Non } \\
\text { Venomous }\end{array}$ & OP & $x$ & $\checkmark$ & $x$ & & $\begin{array}{l}\text { New } \\
\text { distribution } \\
\text { record }\end{array}$ \\
\hline 25 & $\begin{array}{l}\text { Sibynophis } \\
\text { melanocephalus (Gray, } \\
1834 \text { ) }\end{array}$ & $\begin{array}{l}\text { black-headed collared } \\
\text { snake / Malayan many-tooth } \\
\text { snake }\end{array}$ & Least Concern & $\begin{array}{l}\text { Non } \\
\text { Venomous }\end{array}$ & $\begin{array}{l}\text { Literature } \\
\text { (Report) }\end{array}$ & $\mathrm{X}$ & $x$ & $x$ & & \\
\hline 26 & $\begin{array}{l}\text { Trachischium fuscum } \\
\text { (Blyth, 1854) }\end{array}$ & $\begin{array}{l}\text { blackbelly worm-eating } \\
\text { snake /Darjeeling } \\
\text { wormsnake / Darjelling } \\
\text { oriental slender snake }\end{array}$ & Not Evaluated & $\begin{array}{l}\text { Non } \\
\text { Venomous }\end{array}$ & Literature & $x$ & $x$ & $x$ & & \\
\hline 27 & $\begin{array}{l}\text { Trachischium laeve } \\
\text { (Peracca, 1904) }\end{array}$ & olive oriental slender snake & Not Evaluated & $\begin{array}{l}\text { Non } \\
\text { Venomous }\end{array}$ & Literature & $\mathrm{X}$ & $x$ & $\mathrm{x}$ & & \\
\hline 28 & $\begin{array}{l}\text { Trachischium guentheri } \\
\text { (Boulenger, 1890) }\end{array}$ & $\begin{array}{l}\text { Günther's worm-eating } \\
\text { snake / rosebelly worm- } \\
\text { eating snake }\end{array}$ & Least Concern & $\begin{array}{l}\text { Non } \\
\text { Venomous }\end{array}$ & Literature & $x$ & $\mathrm{x}$ & $\mathrm{x}$ & & \\
\hline 29 & $\begin{array}{l}\text { Fowlea piscator } \\
\text { (Schneider, 1799) }\end{array}$ & $\begin{array}{l}\text { checkered keelback/ Asiatic } \\
\text { water snake }\end{array}$ & Not Evaluated & $\begin{array}{l}\text { Non } \\
\text { Venomous }\end{array}$ & $\begin{array}{l}\text { OP+ } \\
\text { Literature }\end{array}$ & $\sqrt{ }$ & $\sqrt{ }$ & $\checkmark$ & $\sqrt{ }$ & \\
\hline 30 & $\begin{array}{l}\text { Fowlea sanctijohannis } \\
\text { (Boulenger, 1890) }\end{array}$ & St. John's keelback & Not Evaluated & $\begin{array}{l}\text { Non } \\
\text { Venomous }\end{array}$ & Literature & $\sqrt{ }$ & $x$ & $\mathrm{x}$ & & \\
\hline \multicolumn{11}{|c|}{ Family: Elapidae } \\
\hline 31 & $\begin{array}{l}\text { Bungarus niger (Wall, } \\
\text { 1908) }\end{array}$ & greater black krait & Not Evaluated & $\begin{array}{l}\text { Neurotoxic, } \\
\text { deadly } \\
\text { venomous }\end{array}$ & $\begin{array}{l}\text { OP+ } \\
\text { Literature }\end{array}$ & $\sqrt{ }$ & $\sqrt{ }$ & $\sqrt{ }$ & $\sqrt{ }$ & \\
\hline 32 & $\begin{array}{l}\text { Sinomicrurus macclellandi } \\
\text { (Reinhardt, 1844) }\end{array}$ & MacClelland's coral snake & Not Evaluated & $\begin{array}{l}\text { Neurotoxic, } \\
\text { deadly } \\
\text { venomous }\end{array}$ & $\begin{array}{l}\text { OP+ } \\
\text { Literature }\end{array}$ & $\sqrt{ }$ & $\sqrt{ }$ & $\checkmark$ & $\checkmark$ & \\
\hline 33 & $\begin{array}{l}\text { Naja kaouthia (Lesson, } \\
\text { 1831) }\end{array}$ & $\begin{array}{l}\text { Monocled cobra / } \\
\text { Monocellate cobra }\end{array}$ & Least Concern & $\begin{array}{l}\text { Neurotoxic, } \\
\text { deadly } \\
\text { venomous }\end{array}$ & OP & $\sqrt{ }$ & $\sqrt{ }$ & $\checkmark$ & $\sqrt{ }$ & $\begin{array}{l}\text { New } \\
\text { distribution } \\
\text { record }\end{array}$ \\
\hline 34 & $\begin{array}{l}\text { Naja naja (LINNAEUS, } \\
\text { 1758) }\end{array}$ & $\begin{array}{l}\text { spectacled cobra/ common } \\
\text { cobra }\end{array}$ & Not Evaluated & $\begin{array}{l}\text { Neurotoxic, } \\
\text { deadly } \\
\text { venomous }\end{array}$ & OP & $\checkmark$ & $\checkmark$ & $\checkmark$ & $\checkmark$ & $\begin{array}{l}\text { New } \\
\text { distribution } \\
\text { record }\end{array}$ \\
\hline 35 & $\begin{array}{l}\text { Ophiophagus hannah } \\
\text { (Cantor, 1836) }\end{array}$ & King cobra/ Hamadryad & $\begin{array}{l}\text { Vulnerable } \\
\text { A2cd }\end{array}$ & $\begin{array}{l}\text { Neurotoxic, } \\
\text { deadly } \\
\text { venomous }\end{array}$ & $\begin{array}{l}\text { OP+ } \\
\text { Literature }\end{array}$ & $\sqrt{ }$ & $\checkmark$ & $\sqrt{ }$ & $\sqrt{ }$ & \\
\hline \multicolumn{11}{|c|}{ Family: Viperidae } \\
\hline 36 & $\begin{array}{l}\text { Gloydius himalayanus } \\
\text { (Günther, 1864) }\end{array}$ & Himalayan pit viper & Not Evaluated & Haemotoxic & $\begin{array}{l}\text { OP+ } \\
\text { Literature }\end{array}$ & $\sqrt{ }$ & $\sqrt{ }$ & $\sqrt{ }$ & $\sqrt{ }$ & \\
\hline 37 & $\begin{array}{l}\text { Ovophis monticola } \\
\text { (Günther, 1864) }\end{array}$ & $\begin{array}{l}\text { Chinese mountain pit/ } \\
\text { western blotched pit viper/ } \\
\text { Oriental mountain pit viper }\end{array}$ & Least Concern & Haemotoxic & Literature & $x$ & $x$ & $x$ & & \\
\hline 38 & $\begin{array}{l}\text { Trimeresurus albolabris } \\
\text { (Gray, 1842) }\end{array}$ & $\begin{array}{l}\text { White lipped pit viper / } \\
\text { White-lipped Tree Viper }\end{array}$ & Least Concern & Haemotoxic & $\begin{array}{l}\text { OP+ } \\
\text { Literature }\end{array}$ & $\sqrt{ }$ & $\checkmark$ & $\sqrt{ }$ & $\sqrt{ }$ & \\
\hline 39 & $\begin{array}{l}\text { Trimeresurus erythrurus } \\
\text { (Cantor, 1839) }\end{array}$ & $\begin{array}{l}\text { Naga-hill pit viper, redtail } \\
\text { (bamboo) pit viper/ spot- } \\
\text { tailed pit viper }\end{array}$ & Least Concern & Haemotoxic & Literature & $x$ & $x$ & $x$ & & \\
\hline 40 & $\begin{array}{l}\text { Trimeresurus } \\
\text { septentrionalis (Kramer, } \\
1977 \text { ) }\end{array}$ & $\begin{array}{l}\text { Kramer's pit viper / } \\
\text { Himalayan white-lipped pit } \\
\text { viper / Nepal pit viper }\end{array}$ & Not Evaluated & Haemotoxic & $\begin{array}{l}\text { OP+ } \\
\text { Literature }\end{array}$ & $\checkmark$ & $\checkmark$ & $\sqrt{ }$ & $\checkmark$ & \\
\hline \multicolumn{6}{|c|}{ Total } & 28 & 22 & 22 & 23 & \\
\hline
\end{tabular}

